\author{
Supplementary Information
}

\title{
Electrochromism of a Bipolar Reversible Redox-Active Ferrocene-Viologen Linked Ionic Liquid
}

Hironobu Tahara*, Rei Baba, Kodai Iwanaga, Takamasa Sagara and Hiroto Murakami*

Graduate School of Engineering, Nagasaki University

Address: Bunkyo 1-14, Nagasaki 852-8521 (Japan)

E-mail: h-tahara@nagasaki-u.ac.jp; hiroto@nagasaki-u.ac.jp

Contents.

1. Synthesis of $\left[\mathrm{FcC}_{11} \mathrm{VC}_{1}\right][\mathrm{TFSI}]_{2}$

2. Characterization

3. Electrochromic cell construction 


\section{Synthesis of [ $\left.\mathrm{FcC}_{11} \mathrm{VC}_{1}\right][\mathrm{TFSI}]_{2}$.}

a)

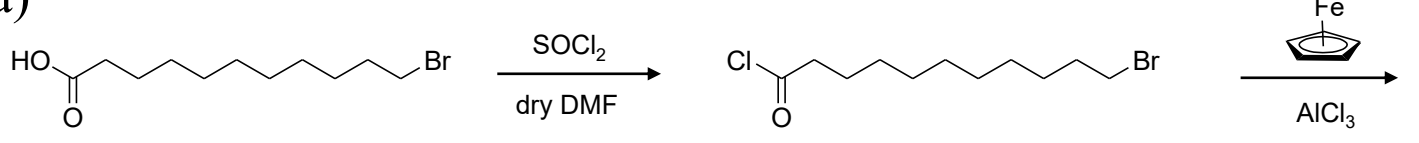<smiles>O=C(CCCCCCCCCCBr)CC[C@H]1CC[C@H]1C1CC1</smiles>

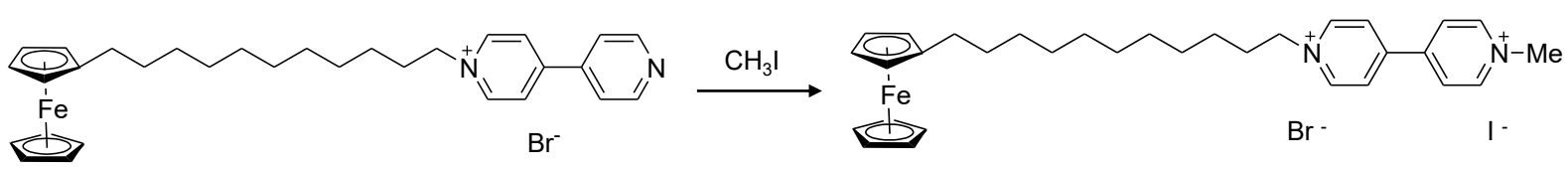

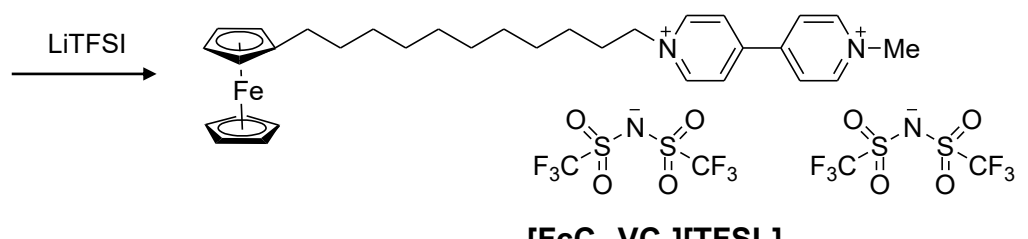

$\left[\mathrm{FcC}_{11} \mathrm{VC}_{1}\right]\left[\mathrm{TFSI}_{2}\right]$

b)

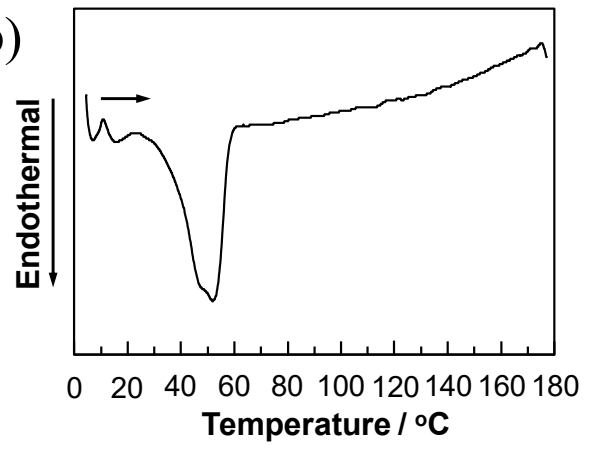

c)

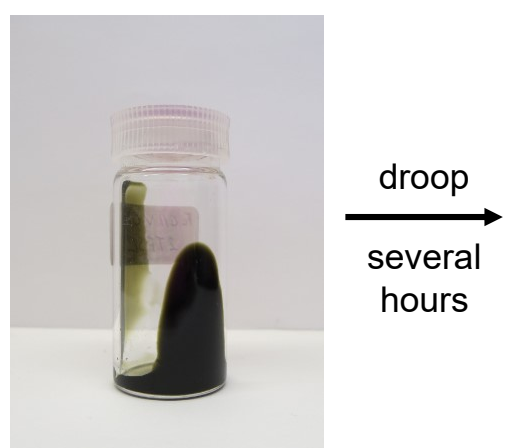

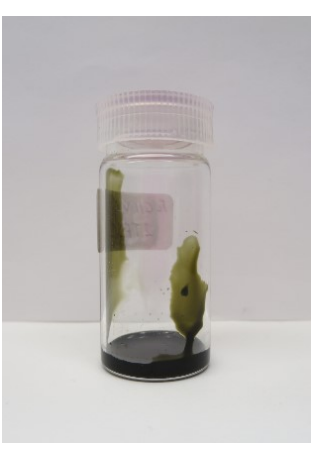

Fig. S1 a) Synthesis, b) DSC thermogram, and c) photographs of [ $\left.\mathrm{FcC}_{11} \mathrm{VC}_{1}\right][\mathrm{TFSI}]_{2}$. 


\section{Preparation of chemicals}

Milli-Q water was used for all experiments. All dry solvents were prepared by single distilling and then stored with appropriate molecular sieves. All chemicals were used as received except particular description.

\section{Synthesis}

A suspension of 11-bromoundecanoic acid $(5.0 \mathrm{~g}, 18.9 \mathrm{mmol})$ in thionyl chloride $(2.7 \mathrm{~mL}, 36.8$ mmol) containing one drop of dry DMF as a catalyst was refluxed for $12 \mathrm{~h}$. After evaporation, the residue was dried at $50{ }^{\circ} \mathrm{C}$ for $3 \mathrm{~h}$. The infrared spectrum of the crude product showed a $\mathrm{C}=\mathrm{O}$ stretching band at $1810 \mathrm{~cm}^{-1}$ assignable to acid chloride. The acid chloride was used without further purification.

A powder of $\mathrm{AlCl}_{3}(5.0 \mathrm{~g}, 36.8 \mathrm{mmol})$ was carefully added to a solution of ferrocene $(7.1$ $\mathrm{g}, 38.4 \mathrm{mmol})$ in dry dichloromethane $(50 \mathrm{~mL})$. The color of the solution turned from light red to dark one. To the dark red solution was added dropwise a solution of the crude acid chloride in dry dichloromethane $(50 \mathrm{~mL})$ at $0{ }^{\circ} \mathrm{C}$. The color turned into purple. The reaction mixture was stirred overnight at ambient temperature and then poured into water $(100 \mathrm{~mL})$, followed by extraction with ethyl acetate $(100 \mathrm{~mL} \times 4)$. The organic layers were combined and washed with brine $(500 \mathrm{~mL} \times 2)$. After evaporation, the residue was purified by column chromatography $\left(\mathrm{SiO}_{2}\right.$, dichloromethane : hexane $\left.=2: 1 \mathrm{v} / \mathrm{v}\right)$ : yield, $6.3 \mathrm{~g}(77 \%) .{ }^{1} \mathrm{H}$ NMR

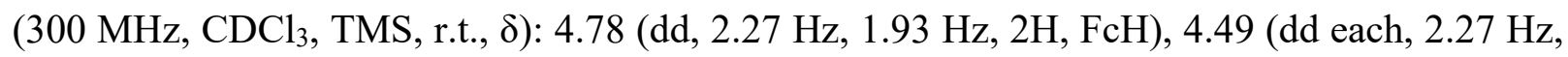


$1.93 \mathrm{~Hz}, 2 \mathrm{H}$ each, FcH), 4.19 (5H, s, FcH), 3.41 (t, $\left.7.29 \mathrm{~Hz}, 2 \mathrm{H}, \mathrm{CH}_{2} \mathrm{Br}\right), 2.69$ (t, $7.46 \mathrm{~Hz}, 2 \mathrm{H}$, $\left.\mathrm{COCH}_{2}\right), 1.85\left(\mathrm{~m}, 2 \mathrm{H}, \underline{\mathrm{CH}_{2}} \mathrm{CH}_{2} \mathrm{Br}\right), 1.69\left(2 \mathrm{H}, \mathrm{m}, \mathrm{COCH}_{2} \mathrm{CH}_{2}\right), 1.61-1.31\left(12 \mathrm{H}, \mathrm{m},\left(\mathrm{CH}_{2}\right)_{6}\right)$.

To a suspension of $\mathrm{LiAlH}_{4}(1.4 \mathrm{~g}, 37 \mathrm{mmol})$ and $\mathrm{AlCl}_{3}(1.3 \mathrm{~g}, 9.7 \mathrm{mmol})$ in dry diethyl ether $(23 \mathrm{~mL})$ in an ice bath under $\mathrm{Ar}$ atmosphere was added dropwise a solution of 11-bromoundecanoylferrocene $(6.1 \mathrm{~g}, 14 \mathrm{mmol})$ in dry diethyl ether $(70 \mathrm{~mL})$ as a rate of one drop per minute. After $0.5 \mathrm{~h}$, a solution of $\mathrm{AlCl}_{3}(1.2 \mathrm{~g}, 9.0 \mathrm{mmol})$ in dry diethyl ether $(10 \mathrm{~mL})$ was added to the reaction mixture. The mixture was stirred for $0.5 \mathrm{~h}$ at ambient temperature and then gently refluxed for $0.5 \mathrm{~h}$ under Ar atmosphere. After cooling to ambient temperature, the reaction mixture was poured into ice water $(46 \mathrm{~mL})$. Subsequently, $6 \mathrm{M} \mathrm{H}_{2} \mathrm{SO}_{4}(20 \mathrm{~mL})$ was added carefully into the ice water, which was then further stirred overnight at ambient temperature. The target product was extracted with diethyl ether $(20 \mathrm{~mL} \times 3)$. The organic layers were combined and dried over anhydrous $\mathrm{MgSO}_{4}$, followed by evaporation to obtain the crude product $(6.1 \mathrm{~g}, 103 \%)$. The product was used in the next step without further purification. ${ }^{1} \mathrm{H}$ NMR (300 MHz, $\mathrm{CDCl}_{3}$, TMS, r.t., $\delta$ ): 4.09 (s, 5H, FcH), 4.05, 4.03 (bs each, $2 \mathrm{H}$ each, $\mathrm{FcH}), 3.41\left(\mathrm{t}, 6.74 \mathrm{~Hz}, 2 \mathrm{H}, \mathrm{CH}_{2} \mathrm{Br}\right), 2.31$ (t, $\left.7.39 \mathrm{~Hz}, 2 \mathrm{H}, \mathrm{FcCH}_{2}\right), 1.85(\mathrm{~m}, 2 \mathrm{H}, 1.69$, $\left.\underline{\mathrm{CH}_{2}} \mathrm{CH}_{2} \mathrm{Br}\right), 1.69\left(2 \mathrm{H}, \mathrm{m}, \mathrm{FcCH}_{2} \underline{\mathrm{CH}}_{2}\right), 1.55-1.28\left(14 \mathrm{H}, \mathrm{m},\left(\mathrm{CH}_{2}\right)_{7}\right)$.

A solution of the crude 11-bromoundecylferrocene $(0.10 \mathrm{~g}, 0.25 \mathrm{mmol})$ in toluene $(5.0$ $\mathrm{mL})$ was added dropwise to a solution of 4,4'-bipyridyl $(0.38 \mathrm{~g}, 2.4 \mathrm{mmol})$ in toluene $(1.0 \mathrm{~mL})$ at $60{ }^{\circ} \mathrm{C}$ under nitrogen atmosphere at a rate of a few drops per second. After stirring for $48 \mathrm{~h}$ at 
$70{ }^{\circ} \mathrm{C}$, the precipitate generated was collected by centrifugation $(1890 \times g)$, washed with toluene and hexane, and then dried at $40{ }^{\circ} \mathrm{C}$ for $6 \mathrm{~h}$ in vacuo to obtain a reddish brown solid

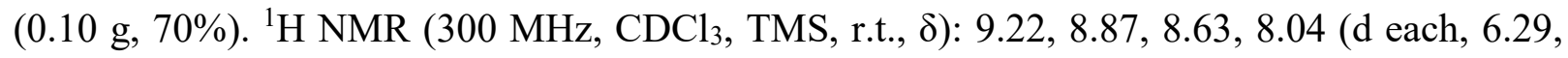
5.02, 6.30, $5.05 \mathrm{~Hz}, 2 \mathrm{H}$ each, $\mathrm{PyH}), 4.61$ (t, 7.6 Hz, 2H, $\left.\mathrm{CH}_{2} \mathrm{Py}\right), 4.08$ (5H, s, FcH), 4.06, 4.02 (bs each, 2H each, FcH), 2.27 (t, $7.12 \mathrm{~Hz}, 2 \mathrm{H}, \mathrm{CH}_{2} \mathrm{Fc}$ ), 1.94 (m, 2H, $\left.\underline{\mathrm{CH}_{2}} \mathrm{CH}_{2} \mathrm{Py}\right), 1.44$ (m, 2H, $\left.\underline{\mathrm{CH}_{2}} \mathrm{CH}_{2} \mathrm{Fc}\right), 1.25\left(\mathrm{~m}, 14 \mathrm{H},\left(\mathrm{CH}_{2}\right)_{7}\right)$.

A solution of 1-(11-ferrocenylundecyl)-4-(4-pyridyl)-pyridinium bromide (53 mg, 92 $\mu \mathrm{mol})$ and iodomethane $(1.0 \mathrm{~mL}, 16 \mathrm{mmol})$ in dichloromethane $(2.0 \mathrm{~mL})$ was stirred at ambient temperature for $12 \mathrm{~h}$. After evaporation, the residue was dissolved in a small amount of methanol and then added dropwise to dichloromethane to obtain the target viologen as a precipitate. The precipitate was collected by centrifugation $(1890 \times g)$, and then dried at $40{ }^{\circ} \mathrm{C}$ for $6 \mathrm{~h}$ in vacuo to obtain a reddish brown solid (46 mg, 70\%). ${ }^{1} \mathrm{H} \mathrm{NMR}\left(300 \mathrm{MHz}, \mathrm{CDCl}_{3}\right.$,

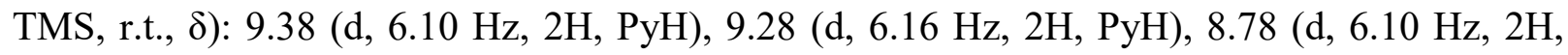
PyH), 8.75 (d, 6.16 Hz, 2H, PyH), 4.67 (t, 7.38 Hz, 2H, $\left.\mathrm{CH}_{2} \mathrm{Py}\right), 4.44$ (s, 3H, $\mathrm{CH}_{3} \mathrm{Py}$ ), 4.08 (s, 5H, FcH), 4.06 (bs, 2H, FcH), 4.03 (bs, 2H, FcH), 2.28 (t, 7.70 Hz, 2H, $\left.\mathrm{CH}_{2} \mathrm{Fc}\right), 1.97$ (m, 2H, $\left.\underline{\mathrm{CH}_{2}} \mathrm{CH}_{2} \mathrm{Py}\right), 1.44\left(\mathrm{~m}, 2 \mathrm{H}, \underline{\mathrm{CH}_{2}} \mathrm{CH}_{2} \mathrm{Fc}\right), 1.26\left(\mathrm{~m}, 14 \mathrm{H},\left(\mathrm{CH}_{2}\right)_{7}\right)$.

1-(11-Ferrocenylundecyl)-1'-methyl-4,4'-bipyridinium $\left(\mathrm{FcC}_{11} \mathrm{VC}_{1}\right)$ bromide iodide (1.03 g, $1.43 \mathrm{mmol}$ ) and lithium bis(trifluoromethanesulfonyl)imide (LiTFSI, $4.12 \mathrm{~g}, 14.3 \mathrm{mmol}$ ) were dissolved in methanol $(100 \mathrm{~mL})$ at $60{ }^{\circ} \mathrm{C}$. After stirring at $60{ }^{\circ} \mathrm{C}$ overnight, the reaction 
mixture was cooled to ambient temperature. After filtration to remove residual unexchanged bipyridinium, the mother liquid was evaporated in vacuo. The residue was dissolved in dichloromethane $(30 \mathrm{~mL})$, and then washed several times with water $(10 \mathrm{~mL})$ until no halide ions were detected in the water phase by a drop test with silver nitrate. The organic layer was passed through hydrophobic filter paper, evaporated in vacuo, and then dried at $80{ }^{\circ} \mathrm{C}$ for $24 \mathrm{~h}$ in vacuo. The $\mathrm{Fc}-\mathrm{V}$-linked $\mathrm{RAIL}\left[\mathrm{FcC}_{11} \mathrm{VC}_{1}\right][\mathrm{TFSI}]_{2}$ was obtained as a brown viscous liquid (1.35 g, 88\%). FAB-MS (m/z): $280\left[\mathrm{TFSI}^{-}\right], 510.4\left[\mathrm{FcC}_{11} \mathrm{~V}^{+\bullet} \mathrm{C}_{1}\right], 790\left[\left(\mathrm{FcC}_{11} \mathrm{~V}^{++} \mathrm{C}_{1}\right) \bullet \mathrm{TFSI}^{-}\right]$, $1070\left[\left(\mathrm{Fc}^{+} \mathrm{C}_{11} \mathrm{~V}^{++} \mathrm{C}_{1}\right) \bullet\left(\mathrm{TFSI}^{-}\right)_{2}\right], 1350.1\left[\left(\mathrm{FcC}_{11} \mathrm{~V}^{++} \mathrm{C}_{1}\right) \bullet\left(\mathrm{TFSI}^{-}\right)_{3}\right]$

\section{Characterization}

X-ray fluorescence measurements were performed on an EDX-800HS spectrometer (Shimadzu Corporation, Kyoto, Japan). MS analysis was measured on a JMS-700N spectrometer (JEOL Ltd., Tokyo, Japan). Elemental analysis was carried out with 2400II (Perkin Elmer Co., Ltd.). Melting point was determined with DSC-60 (Shimadzu Corporation) at a scan rate of $10^{\circ} \mathrm{C}$ $\min ^{-1}$. CVs were obtained using an electrochemical cell with a three-electrode configuration; including an $\mathrm{Au}$ electrode (area: $0.0201 \mathrm{~cm}^{2}$ ), $\mathrm{Ag}$ wire, and $\mathrm{Au}$ coil were used as a working electrode, quasi-reference electrode, and counter electrode, respectively. The solution composition was $1.0 \mathrm{mM}\left[\mathrm{FcC}_{11} \mathrm{VC}_{1}\right][\mathrm{TFSI}]_{2}$ in $0.1 \mathrm{M}$ potassium TFSI acetonitrile solution. The CV measurements were carried out at room temperature with sweep rate of $100 \mathrm{mV} \mathrm{s}^{-1}$. 
Color changes were monitored by a fiber spectrophotometer with HR4000CG-UV-NIR (Ocean Optics, Florida, USA) equipped with a Xe lamp (Hamamatsu Photonics K. K., Shizuoka, Japan) and potentiostat Model 1110 (Huso, Kanagawa, Japan).

\section{Electrochromic cell construction}

Two-electrode cells were constructed using ITO glass substrates (Geomatec Co., Ltd., Kanagawa, Japan; sheet resistance: $10 \Omega /$ sq, ITO thickness: $200 \mathrm{~nm}$ ). A Himilan ${ }^{\odot}\left(\right.$ DuPont $^{\mathrm{TM}}$ ) thermal fusion bonding film (obtained from Peccell Technologies, Inc., Kanagawa, Japan; thickness: $25 \mu \mathrm{m}$ ) was used to define the electrode area of $10 \times 10 \mathrm{~mm}$. $\left[\mathrm{FcC}_{11} \mathrm{VC}_{1}\right][\mathrm{TFSI}]_{2}$ was dropped on the ITO glass, and then sandwiched with another ITO glass with the Himilan ${ }^{\odot}$ film. The thermal fusion was performed on a hotplate at $120^{\circ} \mathrm{C}$. 

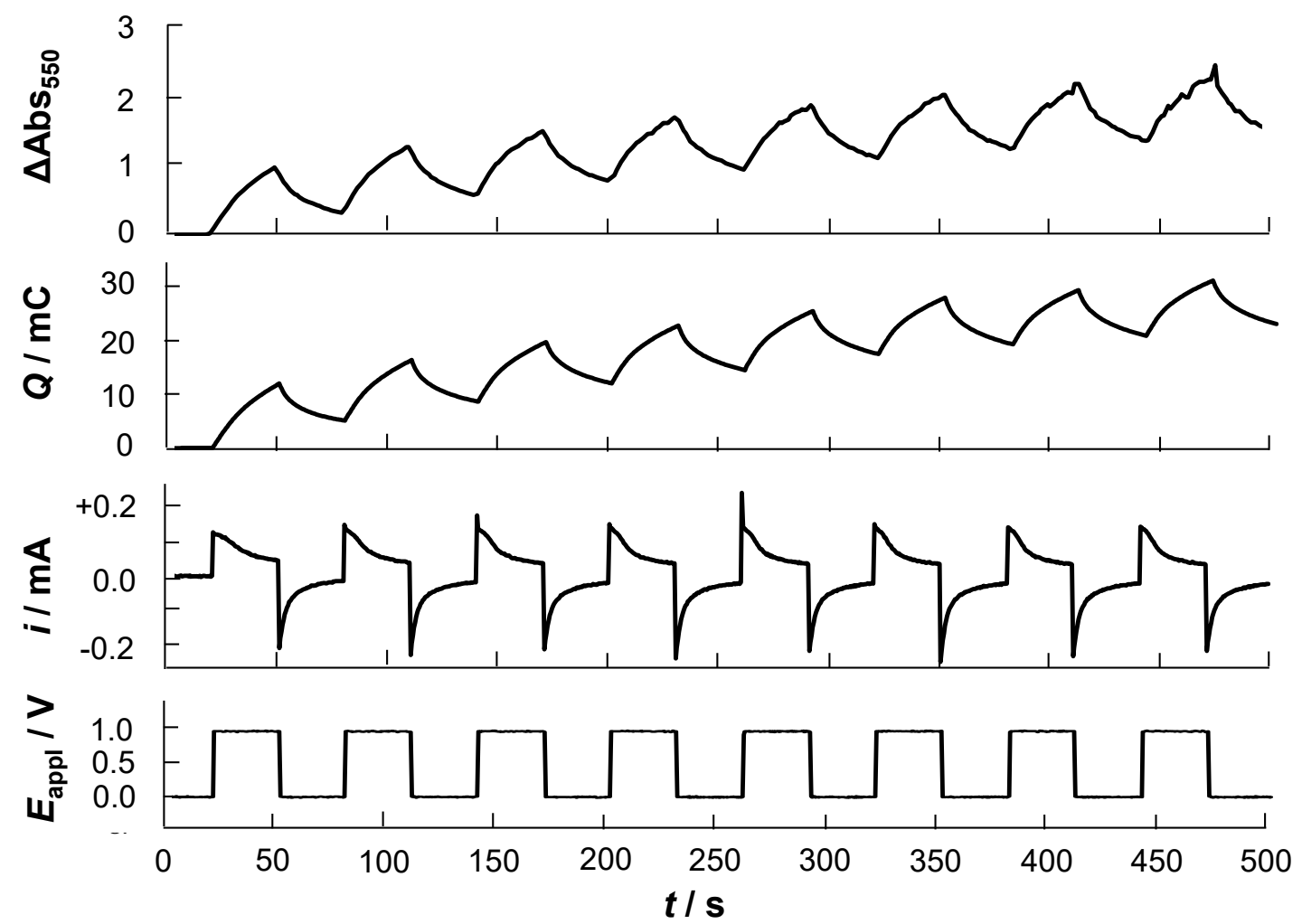

Fig. S2 Time course of absorbance at $550 \mathrm{~nm}\left(\Delta \mathrm{Abs}_{550}\right)$, electric charge $(Q)$, current $(i)$ on the applied potential step $\left(E_{\text {appl }}=0.0\right.$ and $\left.1.0 \mathrm{~V}\right)$ step cycles every $30 \mathrm{~s}$. 